School of Finance

University of St.Gallen

«DOES QUANTITATIVE EASING MITIGATE THE SOVEREIGN-BANK NEXUS?»

AleXANDer Bechtel

JENS EISENSCHMIDT

ANGelo RANALDo

WORKING PAPERS ON FINANCE NO. 2021/01

SWISS INSTITUTE OF BANKING AND FINANCE (S/BF - HSG)

JANUARY 6, 2021 


\title{
Does Quantitative Easing mitigate the Sovereign-Bank Nexus?*
}

\author{
Alexander Bechtel ${ }^{\dagger}$ University of St. Gallen \\ Jens Eisenschmidt ${ }^{\ddagger}$ European Central Bank \\ Angelo Ranaldo ${ }^{\S}$ University of St. Gallen
}

January 6, 2021

\footnotetext{
${ }^{*}$ We thank Sven Klinger, Agnese Leonello, and Hee Su Roh for valuable comments. We also thank Filippo Cavalerie and Eduard Llorens i Jimeno for providing excellent research assistance.

${ }^{\dagger}$ E-mail: alexander . bechtel@unisg.ch.

${ }^{\ddagger}$ E-mail: jens.eisenschmidt@ecb.int.

$\S$ E-mail: angelo.ranaldo@unisg.ch.
} 


\title{
Does Quantitative Easing mitigate the Sovereign-Bank Nexus?
}

\author{
January 6, 2021
}

\begin{abstract}
The credit risk of the sovereign affects the financial health of its banking sector and vice versa, creating an adverse feedback loop known as "sovereignbank nexus". We show that Quantitative Easing can effectively mitigate the sovereign-bank nexus. Our results indicate that the ECB's Public Sector Purchase Programme reduced the co-movement of sovereign and bank credit risk by almost $80 \%$. The mitigation is driven by the euro area periphery and works through three channels: (i) a reduction in government bond holdings of banks, (ii) an increase of government bond prices, and (iii) an increase in excess liquidity holdings of banks.
\end{abstract}

KEYwords: Sovereign-bank nexus, quantitative easing, Public Sector Purchase Programme, financial stability

JEL Codes: E52, G10, E60, G21 


\section{Introduction}

Sovereign and bank credit risks do not only increase individually during crises, they also reinforce each other leading to adverse feedback effects or "diabolic" loops. The origins and dynamics of these loops, also known as "sovereign-bank nexus" (nexus), have been studied extensively. Likewise, policy responses aiming at eliminating or mitigating the nexus have received significant attention in the literature, pointing to a mixed track record. ${ }^{1}$ Nevertheless, we know little about the effectiveness of policies that do not aim to address the nexus directly, but which are operating on all important dimensions affecting it. Large-scale government bond purchases by central banks, also known as Quantitative Easing (QE), are a case in point as they tend to affect the price and volume of outstanding sovereign debt as well as banks and their balance sheets. Surprisingly, even though QE has arguably been one of the most important policy tools of the last decade, its impact on the nexus has, to the best of our knowledge, never been systematically studied. This paper aims to close this gap.

We show that QE can effectively mitigate the nexus. We analyze the effect of government bond purchases in the euro area and show that the Public Sector Purchase Programme (PSPP) of the European Central Bank (ECB) has significantly attenuated the nexus. The co-movement of sovereign and bank credit risk decreased by almost $80 \%$ after the start of the PSPP in March 2015. This reduction is mainly driven by the euro area periphery. The transmission channels that mitigate the feedback loop between sovereign and bank credit risk are (i) a reduction in government bond holdings of banks, i.e., banks are less exposed to their sovereign,

\footnotetext{
${ }^{1}$ See Fratzscher and Rieth (2019) for a recent literature review.
} 
(ii) an increase of government bond prices, i.e., banks' equity position improves, reducing banks' riskiness, and (iii) an increase in excess liquidity holdings of banks, i.e., banks decrease their holdings of a risky asset (euro area periphery government bonds) and increase their holdings of a riskless asset (central bank reserves). ${ }^{2}$

The close link between sovereign and bank risk was laid bare during the global financial crisis 2007-2009 and in particular during the European sovereign debt crisis 2009-2012. This interlinkage has proven to be an important source of systemic risk, aggravating existing vulnerabilities and leading to adverse feedback loops between sovereign and bank risk. In Greece, the deteriorating sovereign creditworthiness became a solvency issue for the banking sector. In Ireland, the dynamics worked in the opposite direction, with risks in the financial sector spilling over to the sovereign. In both cases, sovereign and bank credit risk started to co-move in vicious circles.

The nexus has become even more relevant in light of the current economic crisis that has been triggered by the outbreak and the spread of the coronavirus (COVID-19). In response to the crisis, many governments embarked on massive stabilization efforts through government spending that increased public debt and concomitantly sovereign risk. Simultaneously, credit risk in the banking sector has increased considerably in light of the uncertain economic outlook and potential future losses. This raises concerns about a strong revival of the nexus. Central banks try to address the economic fallout from COVID-19 and its impact on banks and financial markets by extending existing unconventional policies or even by introducing entirely new, dedicated programs such as the ECB's Pandemic

\footnotetext{
${ }^{2}$ We define excess liquidity as banks' recourse to the current account and deposit facility less the minimum reserve requirement.
} 
Emergency Purchase Programme (PEPP).

The close link between sovereign and bank credit risk originates from implicit or explicit public guarantees to banks and from the typically significant domestic government bond holdings of the banking sector (e.g., Acharya, Drechsler, and Schnabl, 2014; Gennaioli, Martin, and Rossi, 2014; Leonello, 2018; Dell'Ariccia, Ferreira, Jenkinson, Laeven, Martin, Minoiu, and Popov, 2018). QE affects the nexus directly and indirectly. The direct effect of $\mathrm{QE}$ on the nexus is that it reduces the amount of government bonds owned by banks while simultaneously increasing the value of sovereign debt that remains on banks' balance sheets and increasing banks' holdings of risk-free central bank reserves. All these effects work in the direction of lowering the overall riskiness of banks emanating from their sovereign bond holdings. Therefore, through the direct channel, QE should mitigate the feedback loop between sovereign and bank credit risk by weakening the link between the two sectors.

The indirect effect of QE on the sovereign-bank nexus works through the impact of QE on banks' balance sheet positions that are not directly related to banks' holdings of sovereign bonds. The overall sign of the indirect effect is unclear. On the one hand, QE should further decrease banks' riskiness through its positive effect on economic activity, leading to lower loan loss provisions and higher credit demand, contributing to an improvement of the equity position of banks. This should in turn weaken the link between the sovereign and its banks (e.g., Altavilla, Boucinha, and Peydró, 2018). On the other hand, QE lowers long-term yields and induces bank risk taking (search-for-yield) and this effect should decrease banks' equity exposing banks more to a deterioration in the credit risk of their sovereign (e.g., Kurtzman, Luck, and Zimmermann, 2018; Darracq Pariès, Körner, and Papadopoulou, 2019; 
Crosignani, Faria-e Castro, and Fonseca, 2019). Consequently, while the direct effect immediately and automatically mitigates the link between banks and their sovereign, the two indirect effects might offset each other and only become effective with some delay.

In our empirical analysis, we provide evidence for the effects of $\mathrm{QE}$ on the nexus. We concentrate on measuring the impact of the direct effects while controlling for the indirect effects. To this end, we follow and extend the methodology of Acharya, Drechsler, and Schnabl (2014), who examine the link between sovereign and bank credit risk in Europe during the Global Financial Crisis and the European Sovereign Debt Crisis 2007-2011. We exploit data on sovereign and bank CDS spreads between January 2014 and December 2016. Before the start of the PSPP on 9 March 2015, a $10 \%$ increase in the sovereign CDS spread leads to a $1.2 \%$ increase in the bank CDS spread. In the post-PSPP period, a $10 \%$ increase in the sovereign CDS spread only leads to a $0.2 \%$ increase in the bank CDS spread. This amounts to a reduction in the co-movement between sovereign and bank credit risk by almost $80 \%$. It is noteworthy that the nexus is mitigated, even though both sovereign and bank credit risk individually increase after the start of the PSPP. This indicates that the direct effect of $\mathrm{QE}$ is the dominant force because the indirect effect relies on an improvement of general economic conditions. Our results also indicate that the sovereign-bank nexus as well as its mitigation is mainly driven by the euro area periphery.

We provide additional evidence for the different channels through which QE mitigates the nexus directly, namely a (i) decrease in government bond holdings, (ii) increase in government bond prices, and (iii) increase in excess liquidity holdings. To this end, we sort banks according to the fraction of their bond portfolio sold 
during the PSPP, their pre-PSPP government bond holdings, and their increase in excess liquidity holdings. We find that the co-movement of sovereign and bank credit risk is reduced especially for banks that (i) sell a bigger fraction of their bond portfolio, (ii) hold more government bonds before the start of the PSPP (and hence are more affected by subsequent changes in prices), and (iii) increase their excess liquidity holdings more. This indicates that all three channels that represent the direct effect of QE on the nexus are active.

We contribute to two strands in the literature: First, we add to existing research on the sovereign-bank nexus. Allen, Carletti, Goldstein, and Leonello (2018) show that public guarantees can affect banks' liquidity creation and the likelihood of runs. Gennaioli, Martin, and Rossi (2014) present a model in which government default dries up banks' liquidity and therefore the government's incentive to bail out banks depends on banks' holdings of public bonds. Furthermore, banks anticipation of government bailouts disincentives equity issuance and incentivizes them to invest into government debt (Cooper and Nikolov, 2018).

Acharya, Drechsler, and Schnabl (2014) take banks' government bond holdings as given and build a theoretical model of the two-way feedback loop between financial sector and sovereign credit risks. On the one hand, financing bailouts is costly because increased taxation induces the corporate sector to underinvest, which in turn erodes the creditworthiness of the sovereign. On the other hand, higher sovereign credit risk feeds back into the financial sector holding a significant share of government debt and reliant on government guarantees. Farhi and Tirole (2018) add a cross-border dimension to the sovereign-bank nexus. In their model, sovereigns anticipate assistance or debt forgiveness from foreign investors because these investors would suffer from a collateral damage in case of a default. This 
creates a moral hazard because sovereigns are less incentivized to control the banking sector tightly as they share risks with others. We contribute to this literature by clearly documenting that flagship central bank policies aimed at easing monetary policy (QE in our case) can have, as a side effect, a powerful mitigating impact on the nexus.

Second, we contribute to the literature on the effects of QE on financial markets. This literature usually focuses on the transmission channels of large-scale government bond purchases to government bond yields (e.g., Gagnon, Raskin, Remache, and Sack, 2011; Krishnamurthy, Nagel, and Vissing-Jorgensen, 2018). There is little evidence, however, on the effect of QE on financial stability, especially on the feedback loop between sovereign and bank risk. Fratzscher and Rieth (2019) provide empirical evidence for a two-way causality between sovereign risk and bank risk in the euro area, taking into account various unconventional monetary policies, such as the ECB's longer-term refinancing operations. On the other hand, the central bank support can create unintended, adverse effects such as excessive illiquid leverage in the financial sector (Acharya and Tuckman, 2014), delayed portfolio adjustments of worthless assets (Bolton, Santos, and Scheinkman, 2009), and a disincentive to sell illiquid assets (Diamond and Rajan, 2011). We contribute to this literature by examining, for the first time, the impact of $\mathrm{QE}$ on the sovereign-bank nexus. Additionally, we provide empirical evidence for the channels through which QE affects the nexus, pointing at the important impact of portfolio rebalancing: A substitution of government bonds and central bank reserves can act as a circuit breaker for the nexus. Koijen, Koulischer, Nguyen, and Yogo (2017) study portfolio rebalancing during the ECB's PSPP. Christensen and Krogstrup (2018) examine the role of central bank reserves in the transmission of QE. 
The remaining paper is structured as follows: In Section 2, we present the channels through which QE mitigates the sovereign-bank nexus. Section 3 provides empirical evidence for the mitigating effect of QE on the nexus. Finally, in Section 4, we discuss several policy implications of our findings and in Section 5, we conclude.

\section{Channel}

\section{$2.1 \quad$ Intuition}

Figure 1 illustrates the channels through which QE can mitigate the sovereign-bank nexus. The left panel shows the feedback loop between bank and sovereign credit risk before the start of large-scale government bond purchases. The top arrow illustrates the first part of the sovereign-bank feedback loop. It shows how sovereign risk can be transmitted to bank risk through the sovereign debt holdings of banks: An increase in sovereign credit risk reduces the value of banks' holdings of sovereign debt and acts as a shock to banks' equity. The quality of the loan portfolio of the bank might also suffer from the shock to sovereign risk. This increases the debt-to-equity ratio further and puts additional pressure on the solvency of the bank.

The arrows at the bottom of Figure 1 illustrate how the decreased solvency of banks feeds back to sovereign credit risk. There are two channels: First, the reduced solvency of the banking sector increases the probability that banks have to be bailed out. A higher likelihood of bank bailouts worsens the sovereign creditworthiness, creating a bailout loop. Second, the reduced solvency and increased leverage of banks hampers credit creation and therefore lowers investment, economic growth, 
and tax revenue. This weakens the solvency of the government, creating a credit or real-economy loop.

[Figure 1 around here.]

The right panel of Figure 1 illustrates the situation after the central bank has started large-scale government bond purchases. During this process, banks sell government bonds to the central bank in return for default-free central bank reserves, which end up as excess liquidity on banks' balance sheets.

This portfolio rebalancing — which we call the direct effect of QE-weakens the feedback loop between sovereign and bank credit risk for three reasons: First, domestic government bond holdings constitute a lower fraction of banks' balance sheets. Consequently, a shock to sovereign credit risk has a smaller effect on banks' equity and hence their leverage and solvency. This alleviates the bailout and credit loop and thus mitigates the sovereign-bank nexus as a whole. Second, the large-scale government bond purchases of the central bank lead to an increase in government bond prices. This has a direct positive effect on the equity of banks, as banks hold significant amounts of government bonds. Third, QE increases banks' holdings of central bank reserves. Reserves are a default-free, safe asset that is uncorrelated with the risk profile of other assets on banks' balance sheets. Consequently, an increasing fraction of reserve holdings makes the balance sheet of a bank more robust and hence mitigates the exposure of banks to credit risk shocks. 


\subsection{Balance sheet model}

We can formalize the direct effect of QE on the sovereign-bank nexus in a simple balance sheet model. The assets of the banking sector consist of government bonds $G$, central bank reserves $R$, and loans to the economy $L$. These assets are financed through deposits $D$ and equity $E$ :

$$
E=G+R+L-D
$$

We can rewrite the nominal amount $G$ as $P_{G} Q_{G}$, where $P_{G}$ denotes the price of the bonds and $Q_{G}$ the outstanding amount.

In this simple setting, a shock to sovereign credit risk, i.e., a shock to $P_{G}$, has the following effect on the equity of the banking sector:

$$
\frac{\partial E}{\partial P_{G}}=Q_{G}
$$

This enables us to make two statements about the effect of QE on the sovereignbank nexus: First, the positive sign of the derivative shows that an increase in government bond prices triggered by QE has a positive effect on the equity of banks. This makes the balance sheets of banks more robust to exogenous shocks and hence should mitigate the nexus. Second, the derivative shows that the magnitude of the effect of bond prices on bank equity depends on the size of the domestic government bond holdings. Since these holdings decrease due to QE, a potential negative shock to sovereign risk has less severe consequences to banks' equity. This should also mitigate the nexus.

QE does not only reduce the government bond holdings of banks, it also increases 
their excess liquidity holdings. Additional excess liquidity makes the balance sheet of a bank more robust. In order to measure the stability of banks' balance sheets, we compute the capital adequacy ratio (CAR), which is defined as the ratio of equity over risk-weighted assets (RWA):

$$
C A R=\frac{\mathrm{E}}{\mathrm{RWA}}
$$

where RWA $=\omega_{L} L+\omega_{G} G+\omega_{R} R$. We assume the following ranking for the risk weights of loans, government bonds, and reserves, respectively: $\omega_{L} \geq \omega_{G} \geq \omega_{R}=0$. Hence, loans are more risky than government bonds, which are more risky than central bank reserves. Note, that our CAR measure should be interpreted as one that reflects actual credit risk of financial assets, such as the measures used by banks internally. We abstract from the zero risk weights attached to government bonds in the current regulatory framework.

During QE, RWA decrease because $G$ decreases and $R$ increases. Consequently, the CAR increases creating a bigger "cushion" for potential losses. Equation (3) also enables us to show that the sensitivity of the CAR with respect to government bonds negatively depends on the risk weight of these bonds:

$$
\frac{\partial \mathrm{CAR}}{\partial G}=-\omega_{G} \frac{E}{\left(\omega_{L} L+\omega_{G} G+\omega_{R} R\right)^{2}} \leq 0 .
$$

Consequently, selling government bonds during QE is particularly helpful if these bonds have a high risk weight.

In sum, government bond purchases increase the stability of banks' balance sheets by increasing the share of risk-free assets. Banks' balance sheets become 
more robust to exogenous shocks, which helps to mitigate the sovereign-bank nexus. The mitigation is particularly big if the central bank purchases risky assets.

\section{Empirical Analysis}

\subsection{Data and summary statistics}

In order to test whether the PSPP mitigated the nexus, we collect daily observations of sovereign and bank CDS spreads between 1 January 2014 and 31 December 2016. The dataset covers 58 banks located in 11 different euro area countries, including Austria, Belgium, Finland, France, Germany, Greece, Italy, Ireland, the Netherlands, Portugal, and Spain. We complement this data with monthly balance sheet information and daily excess liquidity holdings from proprietary datasets at the European Central Bank. Our sample of 58 banks captures about $40 \%$ of total bank assets in the 11 countries. The 30 banks from the euro area periphery - which receive a special focus in our empirical analysis - have a market share of more than $47 \%$.

The Public Sector Purchase Programme (PSPP) was announced on 22 January 2015 and started on 9 March 2015. Under the PSPP, the ECB purchases bonds of euro-area governments, agencies, and European institutions. Until the end of 2016, the total purchase volume amounted to EUR 1,273 billion, corresponding to a monthly purchase volume of about EUR 60 billion. Purchases ware allocated across euro area member countries according to their capital key at the ECB. ${ }^{3}$

Table 1 presents summary statistics for all variables in our analysis. We split the

\footnotetext{
${ }^{3}$ For more information about the PSPP, see https://www.ecb.europa.eu/mopo/implement/ omt/html/pspp.en.html.
} 
dataset into two periods, pre- and post-PSPP. Not surprisingly, bank CDS spreads are higher than sovereign CDS spreads in both periods. Additionally, average CDS spreads as well as their variation increases post-PSPP indicating higher general risk in this period. This is also in line with our aggregate measures for volatility (VDAX-NEW) and credit risk (iTraxx Europe). The VDAX-NEW measures the implied volatility of the German stock market index DAX. The iTraxx Europe is a CDS market index and consists of 125 highly liquid European entities with investment grade credit ratings as published by Markit.

[Table 1 around here.]

The summary statistics illustrate an important point: A mitigation of the nexus does not necessarily imply a general improvement in bank and sovereign credit risk. The nexus concerns the feedback loop between these risks and not their levels. Hence, an increase in bank and sovereign credit risk post-QE does not exclude a mitigation of the feedback loop between these two risks through the direct effects of $\mathrm{QE}$, i.e., via reduced government bond and increased excess liquidity holdings as well as through higher government bond prices. Only the indirect effects of QE require an improvement of general economic conditions and perceptions of risk in the banking sector in order to be effective. The summary statistics do not support this. Also, balance sheet statistics such as the share of capital (capital over total assets) and the share of non-performing loans do not paint a clear picture. While the capital share increases by about 1.2 percentage points post-QE, the share of non-performing loans also increases (by 1.5 percentage points). This indicates that loan portfolios did not get more healthy post-QE and hence did not contribute to 
a mitigation of the feedback loop between sovereign and bank credit risk. We still control for indirect effects in our empirical analysis.

Figure 2 plots the domestic government bond and excess liquidity holdings as a share of banks' balance sheets. These are the variables behind the direct effect of $\mathrm{QE}$ on the nexus. The figure shows that euro area banks reduce their government bond and increase their excess liquidity holdings after the start of the PSPP. The dashed vertical line marks the start of the PSPP purchases on 9 March 2015. Until the end of 2016, the average share of government bond holdings of banks' balance sheets decreases from about $5.6 \%$ to below $5 \%$. At the same time, the share of excess liquidity holdings increases from below $0.5 \%$ to more than $2.5 \%$. The reduction in government bond holdings kicks in with a slight delay because in the first months of the program, foreign institutions, which are not part of our sample, were the main sellers of government bonds to the ECB (Koijen, Koulischer, Nguyen, and Yogo, 2019).

[Figure 2 around here.]

\subsection{Identification strategy}

The main challenge when testing whether QE mitigates the sovereign-bank nexus is to identify the direct link between sovereign and bank credit risk. Hence, we have to control for other (unobserved) factors that contemporaneously impact both risks, such as regulation or changes in macroeconomic risk. For instance, changes in expectations about economic growth or employment might lead to changes in sovereign credit risk and at the same time have direct effects on banks' loan and mortgage portfolios. This could lead to a co-movement between sovereign and bank 
credit risk without there being a direct link between the two.

We address this challenge by employing four sets of control variables. First, we capture changes in variables that have market-wide effects on the financial sector by including day fixed effects. Hence, we control for all macro variables and changes in regulation that contemporaneously affect bank and sovereign credit risk.

Second, we control for the exposure of each country's banking sector to foreign credit risk. To this end, we create a foreign exposure measure, which captures changes in banks' credit risk due to changes in sovereign credit risk of foreign countries. We compute this measure as the weighted average of foreign countries' CDS spreads. The weights are based on the size of the foreign exposure relative to the total size of a country's banking sector. Foreign exposures are available in the consolidated banking statistics of the Bank for International Settlements. ${ }^{4}$ The total sizes of euro area sovereign banking sectors are retrieved from the ECB's MFI balance sheet items via the Statistical Data Warehouse. ${ }^{5}$

Third, we control for heterogeneity in the exposure of banks to changes in macroeconomic variables and regulation. To this end, we include bank fixed effects as well as an aggregate measure for volatility (VDAX-NEW) and credit risk (iTraxx Europe). In case of the VDAX-NEW and the iTraxx Europe, we allow for bankspecific coefficients by interacting the indices with our bank fixed effects. The VDAX-NEW captures changes in expectations about aggregate volatility, which are pivotal for the pricing of credit risk. The iTraxx Europe captures variation in CDS spreads that might be caused by shocks specific to the CDS market or changes in market-wide credit risk and liquidity.

\footnotetext{
${ }^{4}$ See, https://www.bis.org/statistics/consstats.htm.

${ }^{5}$ See, https : //sdw. ecb. europa. eu/browse. do?node=9691312.
} 
Fourth, we control for the indirect effects of QE on the nexus by adding balance sheet variables. In particular, we include banks' capital share (capital over total assets) to ensure that the mitigation of the nexus is not driven by deleveraging. We include loan book shares (loans over total assets) to control for an increase in credit demand. And we include the shares of non-performing loans (non-performing loans over total assets) to control for changes in the quality of the loan portfolio.

We estimate the following regression:

$$
\begin{aligned}
\Delta \log \left(\operatorname{Bank} \operatorname{CDS}_{i j t}\right)= & \alpha_{i}+\delta_{t}+\beta \Delta \log \left(\text { Sovereign } \operatorname{CDS}_{j t}\right)+ \\
& \gamma \Delta \log \left(\text { Foreign Exposure } \mathrm{CDS}_{i j t}\right)+\rho_{i} \Delta X_{i j t}+\kappa \Delta Z_{i j t}+\varepsilon_{i j t},
\end{aligned}
$$

where $\Delta \log \left(\right.$ Bank $\left.\operatorname{CDS}_{i j t}\right)$ is the daily change in logged CDS spreads of bank $i$ located in country $j, \Delta \log \left(\right.$ Sovereign $\left.\mathrm{CDS}_{j t}\right)$ is the daily change in logged CDS spreads of sovereign $j, \Delta \log \left(\right.$ Foreign Exposure $\left.\mathrm{CDS}_{i j t}\right)$ is the daily change of the foreign exposure measure, and $\Delta X_{i j t}$ captures changes in the balance sheet control variables and daily changes of aggregate volatility (VDAX-NEW) and the CDS market index (iTraxx Europe), whereby we allow for bank-specific coefficients $\rho_{i}$. Finally, $\Delta Z_{i j t}$ captures the quarterly balance sheet control variables, $\alpha_{i}$ are bank fixed effects, and $\delta_{t}$ are time fixed effects. We cluster the standard errors at the bank level.

\subsection{Results}

Table 2 presents the results. We investigate the link between sovereign and bank credit risk separately before and after the start of the PSPP. Columns (1) to (3) cover the pre-PSPP period from 1 January 2014 to 8 March 2015 and Columns (4) 
to (6) the post-PSPP period from 9 March 2015 to 31 December 2016. For each period, we present the results with and without bank fixed effects, balance sheet controls, and bank-specific coefficients on the CDS market and volatility index.

In the pre-PSPP period, we find a positive and statistically as well as economically significant relation between sovereign and bank credit risk. A $10 \%$ increase in the sovereign CDS price leads to a $0.8-1.2 \%$ increase in the bank CDS spread. This result is robust to including bank-specific controls and suggests there was a feedback loop between bank and sovereign credit risk before the introduction of the PSPP. The size of the effect is similar to the findings of Acharya, Drechsler, and Schnabl (2014) for European banks and sovereigns in the years after the global financial crisis.

In the post-PSPP period, the coefficient is still positive and statistically different from zero, but it has decreased by almost 80\%. A 10\% increase in sovereign CDS spreads only leads to $0.2-0.5 \%$ increase in bank CDS spreads. Recall, that we control for the joint variation of macroeconomic variables and for bank-specific exposure to aggregate volatility and the CDS market. Consequently, it is unlikely that the co-movement between sovereign and credit risk is driven by market-wide shocks. Instead, these results provide empirical evidence for the mitigating effect of the PSPP on the sovereign-bank nexus. The results are also robust to including balance sheet control variables to control for potential indirect effects of QE. We leave out these control variables in our baseline specification and present the results separately in column (3) and (6) because the sample size is reduced significantly when including balance sheet variables.

[Table 2 around here.] 
Columns (7) to (10) of Table 2 show that the co-movement of sovereign and bank credit risk is driven by countries and banks in the euro area periphery. Columns (7) and (9) show the pre- and post-QE relation between sovereign and bank CDS spread for 28 banks from the core euro area, that is, from Austria, Belgium, Germany, Finland, France, and the Netherlands. Columns (8) and (10) capture 30 banks from the euro area periphery, that is, from Ireland, Italy, Greece, Portugal, and Spain. There is no feedback loop between sovereign and bank credit risk in the euro area core, neither before nor after the start of the PSPP.

In the euro area periphery, on the other hand, the feedback loop is highly statistically as well as economically significant. A $10 \%$ increase in the sovereign CDS spread leads to a $1.5 \%$ increase in the bank CDS spread before the start of the PSPP. In the post-PSPP period, the effect is still positive and statistically different from zero, but it decreases to about $0.3 \%$. These results support the concern that the sovereign-bank risk nexus is primarily a problem for the euro area periphery. However, they also suggest that large-scale purchases of periphery government bonds mitigate the feedback loop between sovereign and bank credit risk in these countries.

In the core-periphery analysis and all following empirical models, we do not include balance sheet controls because this would significantly reduce the number of observations. Table A.1 in the Appendix shows that all regression results hold if we include balance sheet controls. We provide additional evidence for the role of indirect effects of $\mathrm{QE}$ on the nexus in the Appendix. Overall, we find that indirect effects play a minor role for the nexus as already suggested by the summary statistics. 


\subsection{Additional evidence on the channels}

In this section, we provide additional evidence for the direct effect of QE on the sovereign-bank nexus. We identified three mechanisms that directly alleviate the nexus: (i) reduction in domestic government bond holdings, (ii) increase in government bond prices, and (iii) increase in excess liquidity holdings. To provide additional evidence for these channels, we focus on periphery banks and rank these banks according to different criteria.

In order to test (i), we sort our banks according to changes in the share of domestic government bond holdings. We label the $50 \%$ of banks that reduce their portfolio of domestic government bonds most as Top and the 50\% with the least reduction as Bottom. We expect the link between sovereign and bank credit risk to weaken more for banks that sell more government bonds.

In order to test (ii), we sort our banks according to their share of domestic government bond holdings pre-QE. To this end, we compute the average holdings share of our banks in the first six months of 2014. This ensures that our ranking is not affected by anticipation effects of the PSPP. We label the $50 \%$ of banks that hold the biggest portfolio share of domestic government bonds as Top and the 50\% with the lowest share as Bottom. We expect the link between sovereign and bank credit risk to weaken more for banks that hold the highest share of bonds because these banks profit most from price increases.

In order to test (iii), we sort our banks according to changes in the share of excess liquidity holdings. We label the $50 \%$ of banks that increase their excess liquidity most as Top and the 50\% with the lowest increase as Bottom. We expect the link between sovereign and bank credit risk to weaken more for banks that 
increase their excess liquidity holdings more. ${ }^{6}$

Table 3 presents the results, including the full set of control variables. The sample includes 21 banks from 5 euro area periphery countries. Columns (1) to (4) present the results for the ranking of banks based on changes in sovereign bond holdings, columns (5) to (8) for the ranking based on pre-QE sovereign bond holdings, and columns (9) to (12) for the ranking based on changes in excess liquidity holdings. The results for the pre-PSPP period are in line with previous results. There is a strong link between sovereign and bank credit risk in the euro area periphery before the start of the PSPP. The only exception is the estimate for the pre-PSPP coefficient of Top banks when ranked according to the pre-QE government bond holdings (column (5)). The point estimate is similar to what we would expect, but it is not significant.

Post-QE, the link between sovereign and bank credit risk weakens across all banks. However, in line with our channels, the relation weakens particularly for banks that (i) strongly reduce their government bond holdings, (ii) hold a bigger portfolio of sovereign bonds pre-QE, and (iii) increase their excess liquidity holdings more. In all three cases the coefficient for Top banks post-QE is statistically not different from zero anymore. Consequently, these banks are not prone to the sovereign-bank risk nexus anymore.

[Table 3 around here.]

\footnotetext{
${ }^{6}$ Note that a reduction in government bond holdings and an increase of excess liquidity are not necessarily two sides of the same coin. The bank that has sold government bonds to the central bank, might decide to lend the reserves to other banks via the interbank market.
} 


\section{Policy implications}

Our paper shows that the large-scale government bond purchases under the PSPP mitigated the sovereign-bank nexus in the euro area. This finding is important for policy makers (e.g. central bankers, public debt managers, and fiscal policy advisors) and market participants, especially in light of recent economic and financial developments following the global spread of the coronavirus. A functioning banking sector is a prerequisite for the orderly transmission of monetary policy impulses. We show that large-scale asset purchases do not only provide additional stimulus in a situation in which short-term rates can no longer be used for that purpose, they also contribute to decoupling the banking sector risk from sovereign risk. This should be beneficial for the transmission of monetary policy, which is particularly relevant for peripheral euro area countries.

More generally, our results highlight the importance of large-scale government bond purchases for financial stability, in particular during crises. We show that QE can mitigate negative effects on financial stability of higher debt levels triggered by expansionary fiscal policy. Thereby, it can alleviate the diabolic loop between sovereign and bank credit risk.

These insights are also crucial for assessing the policy relevance of some new unconventional measures such as the Pandemic Emergency Purchase Program (PEPP) introduced by the ECB. It seems fair to assume a higher risk of sovereign downgrades due to the additional fiscal spending that the pandemic emergency will entail for some euro area countries. 


\section{Conclusion}

Sovereign risk and banking risk are interlinked and mutually reinforcing. Understanding which factors determine the sovereign-bank nexus is important from many points of view, including fiscal policy, monetary policy and financial stability. This is particularly true in view of the economic and financial consequences that are emerging from the coronavirus (COVID-19) crisis.

The contribution of our work is to show that Quantitative Easing (QE) mitigates the sovereign-bank nexus. In a simple balance sheet framework, we show that a simultaneous reduction of banks' holdings of domestic government bonds and an increase in default-free central bank reserves alleviate the nexus.

We then analyze the Public Sector Purchase Programme (PSPP) conducted by the European Central Bank in the euro area and find that the sovereign-bank nexus decreases by almost $80 \%$ after the start of the PSPP. In line with our balance sheet model, the mitigation of the nexus is mainly driven by banks that are located in the euro area periphery. Our results further indicate that the direct effect of $\mathrm{QE}$ on the nexus is dominating and we provide evidence for the three channels through which QE affects the nexus directly: We show that the nexus is mitigated especially for banks that (i) sell a bigger fraction of their bond portfolio, (ii) hold more government bonds before the start of the PSPP (and hence are more affected by subsequent changes in prices), and (iii) increase their excess liquidity holdings more.

Our findings highlight the importance of large-scale government bond purchases for financial stability. This area of research deserves more empirical and theoretical attention. Understanding the impact of $\mathrm{QE}$ on financial stability is crucial for 
a better understanding of the transmission mechanisms of $\mathrm{QE}$, which are still openly debated in the literature. Finally, our findings may also be relevant for the burgeoning literature on zombie lending (e.g., Acharya, Borchert, Jager, and Steffen, 2020; Acharya, Crosignani, Eisert, and Eufinger, 2020), which finds that undercapitalized banks lend on to weak firms and sovereigns. While we do not look at lending to firms, we clearly document that banks have reduced their lending to sovereigns - including the weaker ones in our sample - as a consequence of QE policies. Consequently, it would be interesting to explore the consequences of our findings for banks' lending decision to the corporate sector. 


\section{References}

Acharya, V., I. Drechsler, and P. Schnabl, 2014, "A Pyrrhic Victory? Bank Bailouts and Sovereign Credit Risk," Journal of Finance, 69(6), 2689-2739.

Acharya, V. V., L. Borchert, M. Jager, and S. Steffen, 2020, "Kicking the can down the road: government interventions in the European banking sector," National Bureau of Economic Research, No. 27537.

Acharya, V. V., M. Crosignani, T. Eisert, and C. Eufinger, 2020, "Zombie credit and (dis-)inflation: evidence from Europe," National Bureau of Economic Research, No. 27158.

Acharya, V. V., and B. Tuckman, 2014, "Unintended consequences of LOLR facilities: The case of illiquid leverage," IMF Economic Review, 62(4), 606-655.

Allen, F., E. Carletti, I. Goldstein, and A. Leonello, 2018, "Government guarantees and financial stability," Journal of Economic Theory, 177, 518-557.

Altavilla, C., M. Boucinha, and J.-L. Peydró, 2018, "Monetary policy and bank profitability in a low interest rate environment," Economic Policy, 33(96), 531586.

Bolton, P., T. Santos, and J. A. Scheinkman, 2009, "Market and public liquidity," American Economic Review, 99(2), 594-599.

Brunnermeier, M. K., L. Garicano, P. R. Lane, M. Pagano, R. Reis, T. Santos, D. Thesmar, S. Van Nieuwerburgh, and D. Vayanos, 2016, "The sovereign-bank diabolic loop and ESBies," American Economic Review: Papers $\&$ Proceedings, $106(5), 508-512$. 
Christensen, J. H. E., and S. Krogstrup, 2018, "A Portfolio Model of Quantitative Easing," Working Paper Series Federal Reserve Bank of San Francisco.

Cooper, R., and K. Nikolov, 2018, "Government Debt and Banking Fragility: the Spreading of Strategic Uncertainty," International Economic Review, 59(4), $1905-1925$.

Crosignani, M., M. Faria-e Castro, and L. Fonseca, 2019, "The (Unintended?) consequences of the largest liquidity injection ever," Journal of Monetary Economics, (forthcoming).

Darracq Pariès, M., J. Körner, and N. Papadopoulou, 2019, "Empowering Central Bank Asset Purchases: The Role of Financial Policies," ECB Working Paper Series No. 223\%.

Dell'Ariccia, G., C. Ferreira, N. Jenkinson, L. Laeven, A. Martin, C. Minoiu, and A. Popov, 2018, "Managing the sovereign-bank nexus," ECB Working Paper No. $217 \%$.

Demiralp, S., J. Eisenschmidt, and T. Vlassopoulos, 2019, "Negative interest rates, excess liquidity and retail deposits: banks' reation to unconventional monetary policy in the euro area," ECB Working Paper Series No. 2283.

Diamond, D. W., and R. G. Rajan, 2011, "Fearof fire sales, illiquidity seeking, and credit freezes," Quarterly Journal of Economics, 126(2), 557-591.

Farhi, E., and J. Tirole, 2018, "Deadly embrace: Sovereign and Financial Balance Sheets Doom Loops," Review of Economic Studies, 85(3), 1781-1823. 
Fratzscher, M., and M. Rieth, 2019, "Monetary Policy, Bank Bailouts and the Sovereign-Bank Risk Nexus in the Euro Area," Review of Finance, 23(4), 745-775.

Gagnon, J., M. Raskin, J. Remache, and B. Sack, 2011, "The Financial Market Effects of the Federal Reserve's Large-Scale Asset Purchases," International Journal of Central Banking, 7(1), 3-43.

Gennaioli, N., A. Martin, and S. Rossi, 2014, "Sovereign Default, Domestic Banks, and Financial Institutions," Journal of Finance, 69(2), 819-866.

Koijen, R. S. J., F. Koulischer, B. Nguyen, and M. Yogo, 2017, "Euro-Area Quantitative Easing and Portfolio Rebalancing," American Economic Review Papers and Proceedings, 107(5), 621-627.

Koijen, R. S. J., F. Koulischer, B. Nguyen, and M. Yogo, 2019, "Inspecting the Mechanism of Quantitative Easing in the Euro Area," Working Paper, 100.

Krishnamurthy, A., S. Nagel, and A. Vissing-Jorgensen, 2018, "ECB policies involving government bond purchases: Impact and channels," Review of Finance, $22(1), 1-44$.

Kurtzman, R., S. Luck, and T. Zimmermann, 2018, "Did QE lead banks to relax their lending standards? Evidence from the Federal Reserve's LSAPs," Journal of Banking and Finance, (forthcoming).

Leonello, A., 2018, "Government guarantees and the two-way feedback between banking and sovereign debt crises," Journal of Financial Economics, 130(3), $592-619$. 
Figure 1: Sovereign-bank nexus: Feedback channels

Figure 1 illustrates the channels through which sovereign risk and bank risk are interrelated and how this interrealtion is affected by QE. It is inspired by Brunnermeier, Garicano, Lane, Pagano, Reis, Santos, Thesmar, Van Nieuwerburgh, and Vayanos (2016).

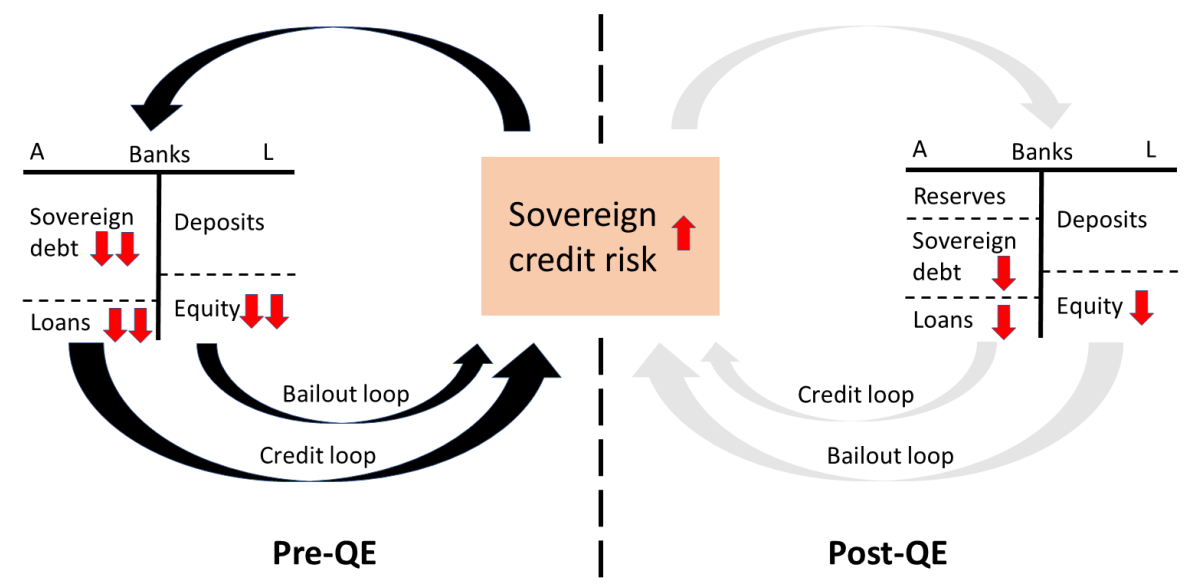

Figure 2: Domestic government bond and excess liquidity holdings

Figure 2 plots the average domestic government bond and excess liquidity holdings of banks as a share of total asset. The figure is based on proprietary balance sheet datasets from the European Central Bank.

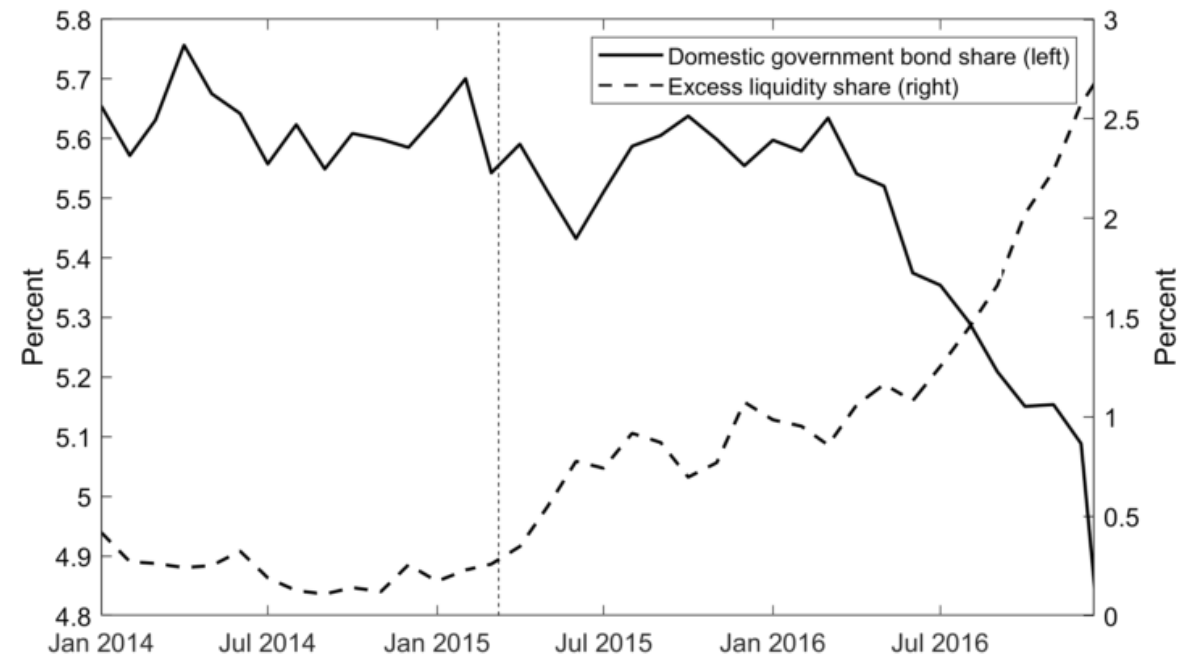


Table 1: Summary statistics

Table 1 presents summary statistics for all variables. Panel (a) covers the pre-PSPP period from 1 January 2014 to 8 March 2015. Panel (b) covers the post-PSPP period from 9 March 2015 - 31 December 2016. All shares are computed as shares of total assets. $N$ is the number of banks for which data on the respective variable is available.

(a) Pre: 1 Jan 2014 - 8 March 2015

\begin{tabular}{llllll}
\hline & Mean & Std & Min & Max & $N$ \\
\hline Bank CDS & 180 & 182 & 37 & 2,310 & 58 \\
Sovereign CDS & 114 & 209 & 16 & 2,272 & 58 \\
Foreign Exposure CDS & 5.03 & 2.92 & 0.78 & 19.40 & 58 \\
Share domestic bond (\%) & 5.63 & 3.27 & -0.18 & 16.19 & 39 \\
Share excess liquidity (\%) & 0.22 & 0.55 & -0.23 & 4.78 & 39 \\
Capital share (\%) & 11.35 & 5.29 & 3.07 & 23.42 & 32 \\
Loan book share (\%) & 38.86 & 14.65 & 10.69 & 63.37 & 32 \\
NPL share (\%) & 8.53 & 7.66 & 1.78 & 30.89 & 32 \\
VDAX-NEW & 18.35 & 3.10 & 12.17 & 28.66 & - \\
iTraxx Europe & 65.01 & 7.41 & 47.67 & 85.23 & - \\
\hline
\end{tabular}

(b) Post: 9 March 2015 - 31 Dec 2016

\begin{tabular}{llllll}
\hline & Mean & Std & Min & Max & $N$ \\
\hline Bank CDS & 274 & 475 & 24 & 7,423 & 58 \\
Sovereign CDS & 169 & 468 & 12 & 8,533 & 58 \\
Foreign Exposure CDS & 5.12 & 3.51 & 0.65 & 25.63 & 58 \\
Share domestic bond (\%) & 5.46 & 3.18 & -0.02 & 16.60 & 39 \\
Share excess liquidity (\%) & 1.11 & 1.89 & -0.25 & 10.80 & 39 \\
Capital share (\%) & 12.51 & 6.08 & 3.50 & 27.89 & 32 \\
Loan book share (\%) & 39.42 & 12.88 & 12.32 & 59.07 & 32 \\
NPL share (\%) & 9.96 & 6.08 & 3.50 & 27.89 & 32 \\
VDAX-NEW & 23.35 & 4.56 & 14.73 & 38.29 & - \\
iTraxx Europe & 74.10 & 11.94 & 49.38 & 125.70 & - \\
\hline
\end{tabular}


Table 2: Change in Bank and Sovereign Credit Risk

Table 2 shows the effect of sovereign credit risk on bank credit risk before and after the introduction of the Public Sector Purchase Programme (PSPP). The sample with daily frequency covers 58 banks with publicly traded credit default swaps (CDS) from 11 different euro area countries. Columns (1) to (3) cover the pre-QE period (1 January 2014 to 8 March 2015) and columns (4) to (6) cover the post-QE period (8 March 2015 to 31 December 2016) for all banks in the sample. We add balance sheet control variables in columns (3) and (6), which reduces the sample size to 32 banks. Columns (7) to (10) distinguish between the origin of banks. Core captures banks from the core euro area, in particular from Austria, Belgium, Finland, France, Germany, and the Netherlands. Periphery includes banks from Greece, Italy, Ireland, Portugal, and Spain. $\triangle \log ($ Bank CDS) is the daily change in the natural logarithm of bank CDS. $\Delta \log ($ Sovereign CDS $)$ is the daily change in the sovereign CDS of the country in which the bank is headquartered. We add a range of control variables, including bank and day fixed effects, the foreign exposure measure $\Delta \log$ (Foreign Exposure CDS), and interactions of bank fixed effects with the change in the CDS market index and the change in the volatility index. t-statistics are in parentheses.

\begin{tabular}{|c|c|c|c|c|c|c|c|c|c|c|}
\hline & \multicolumn{10}{|c|}{$\Delta \log ($ Bank CDS $)$} \\
\hline & \multicolumn{3}{|c|}{ Pre-QE } & \multicolumn{3}{|c|}{ Post-QE } & \multicolumn{2}{|c|}{ Pre-QE } & \multicolumn{2}{|c|}{ Post-QE } \\
\hline & $\begin{array}{l}\text { All } \\
\text { (1) }\end{array}$ & $\begin{array}{l}\text { All } \\
(2)\end{array}$ & $\begin{array}{l}\text { All } \\
(3)\end{array}$ & $\begin{array}{l}\text { All } \\
(4)\end{array}$ & $\begin{array}{l}\text { All } \\
(5)\end{array}$ & $\begin{array}{l}\text { All } \\
(6)\end{array}$ & $\begin{array}{l}\text { Core } \\
(7)\end{array}$ & $\begin{array}{c}\text { Periphery } \\
(8)\end{array}$ & $\begin{array}{l}\text { Core } \\
(9)\end{array}$ & $\begin{array}{c}\text { Periphery } \\
\text { (10) }\end{array}$ \\
\hline$\Delta \log ($ Sovereign CDS) & $\begin{array}{l}0.117 \\
(4.83)\end{array}$ & $\begin{array}{l}0.0804 \\
(3.79)\end{array}$ & $\begin{array}{l}0.111 \\
(2.06)\end{array}$ & $\begin{array}{l}0.0268 \\
(2.35)\end{array}$ & $\begin{array}{c}0.0178 \\
(2.41)\end{array}$ & $\begin{array}{l}0.0475 \\
(1.94)\end{array}$ & $\begin{array}{c}0.00368 \\
(0.14)\end{array}$ & $\begin{array}{l}0.152 \\
(5.00)\end{array}$ & $\begin{array}{c}0.00683 \\
(0.62)\end{array}$ & $\begin{array}{l}0.0347 \\
(3.58)\end{array}$ \\
\hline Time/Bank FE & $\mathrm{Y} / \mathrm{N}$ & $\mathrm{Y} / \mathrm{Y}$ & $\mathrm{Y} / \mathrm{Y}$ & $\mathrm{Y} / \mathrm{N}$ & $\mathrm{Y} / \mathrm{Y}$ & $\mathrm{Y} / \mathrm{Y}$ & $\mathrm{Y} / \mathrm{Y}$ & $\mathrm{Y} / \mathrm{Y}$ & $\mathrm{Y} / \mathrm{Y}$ & $\mathrm{Y} / \mathrm{Y}$ \\
\hline Foreign Exposure CDS & $\mathrm{Y}$ & $\mathrm{Y}$ & $\mathrm{Y}$ & $\mathrm{Y}$ & $\mathrm{Y}$ & $\mathrm{Y}$ & $\mathrm{Y}$ & $\mathrm{Y}$ & $\mathrm{Y}$ & $\mathrm{Y}$ \\
\hline Bank-level betas & $\mathrm{N}$ & $\mathrm{Y}$ & Y & $\mathrm{N}$ & $\mathrm{Y}$ & $\mathrm{Y}$ & Y & Y & Y & $\mathrm{Y}$ \\
\hline Balance sheet controls & $\mathrm{N}$ & $\mathrm{N}$ & Y & $\mathrm{N}$ & $\mathrm{N}$ & Y & $\mathrm{N}$ & $\mathrm{N}$ & $\mathrm{N}$ & $\mathrm{N}$ \\
\hline Observations & 17,806 & 17,806 & 1,413 & 27,550 & 27,550 & 5,612 & 8,596 & 9,210 & 13,300 & 14,250 \\
\hline Banks & 58 & 58 & 32 & 58 & 58 & 32 & 28 & 30 & 28 & 30 \\
\hline$R^{2}$ & 0.151 & 0.193 & 0.402 & 0.181 & 0.242 & 0.388 & 0.239 & 0.202 & 0.383 & 0.211 \\
\hline Adjusted $R^{2}$ & 0.136 & 0.171 & 0.281 & 0.166 & 0.224 & 0.323 & 0.203 & 0.166 & 0.356 & 0.178 \\
\hline
\end{tabular}


Table 3: Change in Bank and Sovereign Credit Risk (top vs. bottom)

Table 3 shows the effect of sovereign credit risk on bank credit risk before and after the introduction of the Public Sector Purchase Programme (PSPP). The sample with daily frequency covers 21 banks with publicly traded credit default swaps (CDS) from 5 different euro area periphery countries. In column (1) to (4), we sort the banks according to their changes in government bond holdings. In column (5) to (8), we sort the banks according to their government bond holdings pre-QE. Finally, in column (9) to (12), we sort banks according to changes in excess liquidity holdings. Top captures the banks that reduce their government bond or excess liquidity holdings more than the median, or banks that hold more government bonds as the median pre-QE. Likewise, Bottom captures the banks that reduce their government bond (excess liquidity) holdings less than the median, or banks that hold less government bonds as the median pre-QE. Columns (1), (2), (5), (6), (9), and (10) cover the pre-QE period (1 January 2014 to 8 March 2015). Columns (3), (4), (7), (8), (11), and (12) cover the post-QE period (9 March 2015 to 31 December 2016). $\Delta$ Log(Bank CDS) is the daily change in the natural logarithm of bank CDS. $\triangle \log ($ Sovereign CDS) is the daily change in the sovereign CDS of the country in which the bank is headquartered. We add a range of control variables, including bank and day fixed effects, the foreign exposure measure $\Delta \log$ (Foreign Exposure CDS), and interactions of bank fixed effects with the change in the CDS market index and the change in the volatility index. t-statistics are in parentheses.

\begin{tabular}{|c|c|c|c|c|c|c|c|c|c|c|c|c|}
\hline & \multicolumn{12}{|c|}{$\Delta \log ($ Bank CDS $)$} \\
\hline & \multicolumn{4}{|c|}{ Ranking: $\Delta$ Sov bond holdings } & \multicolumn{4}{|c|}{ Ranking: Pre-QE sov bond holdings } & \multicolumn{4}{|c|}{ Ranking: $\Delta$ EL holdings } \\
\hline & \multicolumn{2}{|c|}{ Pre-QE } & \multicolumn{2}{|c|}{ Post-QE } & \multicolumn{2}{|c|}{ Pre-QE } & \multicolumn{2}{|c|}{ Post-QE } & \multicolumn{2}{|c|}{ Pre-QE } & \multicolumn{2}{|c|}{ Post-QE } \\
\hline & $\begin{array}{l}\text { Top } \\
\text { (1) }\end{array}$ & $\begin{array}{l}\text { Bottom } \\
(2)\end{array}$ & $\begin{array}{l}\text { Top } \\
(3)\end{array}$ & $\begin{array}{c}\text { Bottom } \\
\text { (4) }\end{array}$ & $\begin{array}{l}\text { Top } \\
(5)\end{array}$ & $\begin{array}{c}\text { Bottom } \\
(6)\end{array}$ & $\begin{array}{l}\text { Top } \\
(7)\end{array}$ & $\begin{array}{l}\text { Bottom } \\
(8)\end{array}$ & $\begin{array}{l}\text { Top } \\
(9)\end{array}$ & $\begin{array}{c}\text { Bottom } \\
(10)\end{array}$ & $\begin{array}{l}\text { Top } \\
\text { (11) }\end{array}$ & $\begin{array}{c}\text { Bottom } \\
\text { (12) }\end{array}$ \\
\hline$\Delta \log ($ Sovereign CDS $)$ & $\begin{array}{c}0.152 \\
(10.26)\end{array}$ & $\begin{array}{l}0.161 \\
(3.18)\end{array}$ & $\begin{array}{l}0.0218 \\
(1.27)\end{array}$ & $\begin{array}{c}0.0391 \\
(3.11)\end{array}$ & $\begin{array}{l}0.164 \\
(1.75)\end{array}$ & $\begin{array}{l}0.163 \\
(3.74)\end{array}$ & $\begin{array}{c}0.0185 \\
(0.35)\end{array}$ & $\begin{array}{l}0.0387 \\
(3.61)\end{array}$ & $\begin{array}{l}0.208 \\
(3.06)\end{array}$ & $\begin{array}{l}0.163 \\
(3.66)\end{array}$ & $\begin{array}{c}0.0199 \\
(0.58)\end{array}$ & $\begin{array}{c}0.0396 \\
(3.23)\end{array}$ \\
\hline Time/Bank FE & $\mathrm{Y} / \mathrm{Y}$ & $\mathrm{Y} / \mathrm{Y}$ & $\mathrm{Y} / \mathrm{Y}$ & $\mathrm{Y} / \mathrm{Y}$ & $\mathrm{Y} / \mathrm{Y}$ & $\mathrm{Y} / \mathrm{Y}$ & $\mathrm{Y} / \mathrm{Y}$ & $\mathrm{Y} / \mathrm{Y}$ & $\mathrm{Y} / \mathrm{Y}$ & $\mathrm{Y} / \mathrm{Y}$ & $\mathrm{Y} / \mathrm{Y}$ & $\mathrm{Y} / \mathrm{Y}$ \\
\hline Foreign Exposure CDS & $\mathrm{Y}$ & $\mathrm{Y}$ & $\mathrm{Y}$ & $\mathrm{Y}$ & $\mathrm{Y}$ & $\mathrm{Y}$ & $\mathrm{Y}$ & $\mathrm{Y}$ & $\mathrm{Y}$ & $\mathrm{Y}$ & $\mathrm{Y}$ & $\mathrm{Y}$ \\
\hline Bank-level betas & $\mathrm{Y}$ & $\mathrm{Y}$ & Y & $\mathrm{Y}$ & $\mathrm{Y}$ & $\mathrm{Y}$ & $\mathrm{Y}$ & $\mathrm{Y}$ & $\mathrm{Y}$ & $\mathrm{Y}$ & $\mathrm{Y}$ & Y \\
\hline Balance sheet controls & $\mathrm{N}$ & $\mathrm{N}$ & $\mathrm{N}$ & $\mathrm{N}$ & $\mathrm{N}$ & $\mathrm{N}$ & $\mathrm{N}$ & $\mathrm{N}$ & $\mathrm{N}$ & $\mathrm{N}$ & $\mathrm{N}$ & $\mathrm{N}$ \\
\hline Observations & 3,070 & 3,377 & 4,750 & 5,225 & 3,377 & 3,070 & 5,225 & 4,750 & 3,377 & 3,070 & 5,225 & 4,750 \\
\hline Banks & 10 & 11 & 10 & 11 & 11 & 10 & 11 & 10 & 11 & 10 & 11 & 10 \\
\hline$R^{2}$ & 0.444 & 0.224 & 0.341 & 0.277 & 0.271 & 0.364 & 0.512 & 0.322 & 0.266 & 0.367 & 0.558 & 0.302 \\
\hline Adjusted $R^{2}$ & 0.376 & 0.138 & 0.263 & 0.200 & 0.190 & 0.286 & 0.459 & 0.242 & 0.184 & 0.289 & 0.510 & 0.219 \\
\hline
\end{tabular}




\section{Appendix}

\section{A.1 Additional potential confounders}

The PSPP coincided with other policies that might impact the relation between sovereign and bank credit risk through one of our channels. This concerns especially the introduction of the single supervisory mechanism (SSM) in September 2014 and other non-standard monetary policies such as targeted longer-term refinancing operations (TLTROs) and the negative interest rate policy (NIRP).

\section{A.1.1 Single supervisory mechanism}

The start of the SSM in September 2014 could affect our results as it may have led to a convergence of banks' domestic sovereign debt holdings across countries due to the centralisation of prudential supervision. While plausible, there is no evidence of a convergence of banks' sovereign debt holdings across euro area countries after the start of the SSM. Figure 2 shows that government bond holdings of banks remained stable in 2014. Additionally, Figure A.1 shows that marked differences in banks' propensity to hold government bonds remain after the start of the PSPP. If anything, banks should have had an incentive to reduce their sovereign bond holdings already before the start of the SSM in the wake of the so-called comprehensive assessment. This was conducted by the ECB and national supervisors to determine the asset quality of euro area banks, which were selected to be supervised by the SSM. The comprehensive assessment was finalized in December 2013, well before the start of the PSPP and to the extent that banks adjusted their positions to be seen in a more favourable light in the comprehensive assessment, any such adjustment will 
not affect our results as the PSPP only started in March 2015.

Figure A.1: Distribution of sovereign bond holding shares

Figure A.1 presents two histograms of the sovereign bond holding shares of banks before and after the start of the PSPP.

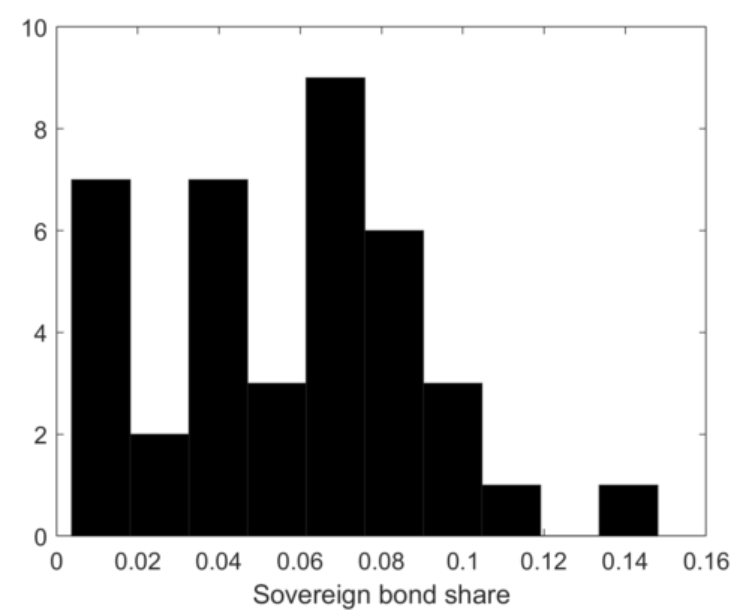

(a) Pre-PSPP

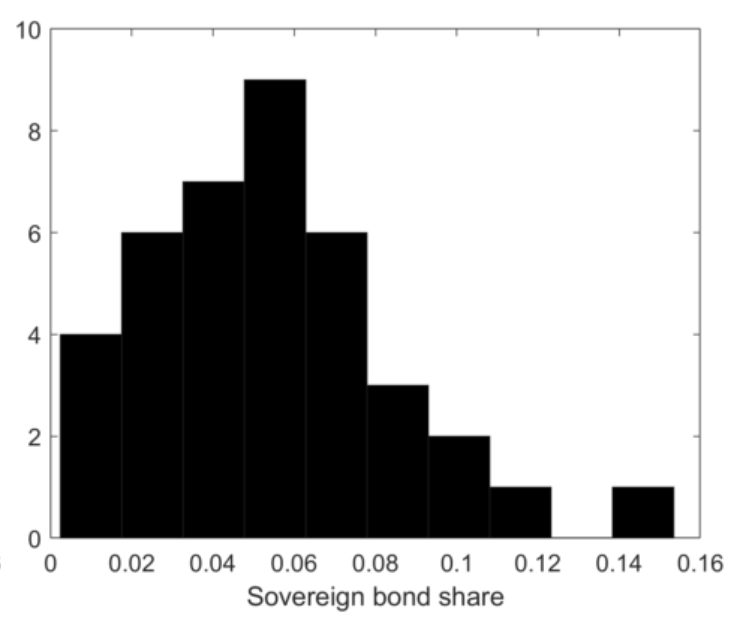

(b) Post-PSPP

\section{A.1.2 Targeted longer-term refinancing operations and neg- ative interest rate policy}

The PSPP was not the only non-standard measures taken by the ECB during the period in which we measure the effects of QE on the nexus. During our sample period, the ECB conducted so-called targeted longer-term refinancing operations (TLTROs) and intensified the use of its negative interest rate policy (NIRP). TLTROs are refinancing operations where the rate paid by banks for their central bank loans is only known ex-post and conditional on the banks meeting specific loan growth targets. For this reason, TLTROs are unlikely candidates to affect 
the nexus as banks engaging in sovereign bond purchases instead of lending to the private sector would risk paying a higher rate for their central bank loans. This renders a simple sovereign carry strategy unattractive. Furthermore, the first TLTRO program - decided in June 2014 and starting with two entry operations in September and December 2014 - pre-dates our sample. If banks did not participate in either the September or the December operation, they were not eligible to participate in any of the following operations. Additionally, their bid amount in the entry operations was decisive for what they could obtain in any of the following operations (running from March 2015 until March 2016). We therefore consider TLTROs unlikely candidates to impact banks' holdings of sovereign bonds. Another non-standard measure running in parallel to the ECB's PSPP is NIRP. Negative interest rates may induce banks to convert their excess liquidity holdings into (sovereign) bonds. Similar to the TLTRO's, NIRP predates the PSPP starting in June 2014. However, two interest rate cuts lie within our sample period (December 2015 and March 2016, 10bps each) and these two cuts may have affected banks' sovereign bond holdings. Extant literature on the impact of NIRP does not find evidence of banks converting their excess liquidity into sovereign bond holdings (e.g., Demiralp, Eisenschmidt, and Vlassopoulos, 2019). Against this background, NIRP should not confound our results.

\section{A.2 Additional regression designs}

Table A.1 presents the baseline regression results including additional balance sheet control variables. In particular, we control for banks' capital share (capital over total assets), their loan book share (loans over total assets), and the share of 
non-performing loans. The sample size is slightly reduced due to data availability. The results are fully consistent with the baseline results from the paper: The feedback loop between sovereign and bank credit risk is mitigated post-QE and this development is mainly driven by the euro area periphery.

Table A.2 presents additional evidence on the role of the indirect channel of QE on the link between sovereign and bank credit risk. As motivated in our balance sheet model, the indirect channel mainly works through banks' loan portfolio. QE should decrease banks' riskiness through positive effects on economic activity, leading to lower loan loss provision and higher credit demand, contributing to an improvement of the equity position of banks and this should in turn weaken the link between the sovereign and its banks (Altavilla, Boucinha, and Peydró, 2018).

Banks with larger loan portfolio should profit more from this effect. Against this background, we sort the banks according to their loan book shares pre-QE. In particular, we compute the average share of loans over total assets from the first half of 2014. Top captures the banks with a share greater than the median. Bottom captures the banks with a share lower than the median. Table A.2 shows that the sovereign-bank nexus is mitigated for both groups. However, there is no significant difference in the reduction of the feedback loop between banks with large and small loan books. This indicates that the indirect channel via loan book shares does not drive our results. 
Table A.1: Change in Bank and Sovereign Credit Risk (inlcuding balance sheet controls)

Table A.1 shows the effect of sovereign credit risk on bank credit risk before and after the introduction of the Public Sector Purchase Programme (PSPP). Compared to the baseline results in Table 2, we add balance sheet control variables, which reduces the sample size to 32 banks. Columns (1) and (2) cover the pre-QE period (1 January 2014 to 8 March 2015) and columns (3) and (4) cover the post-QE period (9 March 2015 to 31 December 2016) for all banks in the sample. Column (5) to (8) distinguish between the origin of banks. Core captures banks from the core euro area, in particular from Austria, Belgium, Finland, France, Germany, and the Netherlands. Periphery includes banks from Greece, Italy, Ireland, Portugal, and Spain. $\Delta \log ($ Bank CDS) is the daily change in the natural logarithm of bank CDS. $\Delta \log ($ Sovereign CDS) is the daily change in the sovereign CDS of the country in which the bank is headquartered. We add a range of control variables, including bank and day fixed effects, the foreign exposure measure $\Delta \log$ (Foreign Exposure CDS), and interactions of bank fixed effects with the change in the CDS market index and the change in the volatility index. t-statistics are in parentheses and the stars ${ }^{* *},{ }^{* *}$, and $*$ indicate statistical significance at the $1 \%, 5 \%$, and $10 \%$ level, respectively.

\begin{tabular}{|c|c|c|c|c|c|c|c|c|}
\hline & \multicolumn{8}{|c|}{$\Delta \log ($ Bank CDS $)$} \\
\hline & \multicolumn{2}{|c|}{ Pre-QE } & \multicolumn{2}{|c|}{ Post-QE } & \multicolumn{2}{|c|}{ Pre-QE } & \multicolumn{2}{|c|}{ Post-QE } \\
\hline & $\begin{array}{l}\text { All } \\
\text { (1) }\end{array}$ & $\begin{array}{l}\text { All } \\
(2)\end{array}$ & $\begin{array}{l}\text { All } \\
\text { (3) }\end{array}$ & $\begin{array}{l}\text { All } \\
(4)\end{array}$ & $\begin{array}{l}\text { Core } \\
(5)\end{array}$ & $\begin{array}{c}\text { Periphery } \\
\text { (6) }\end{array}$ & $\begin{array}{l}\text { Core } \\
(7)\end{array}$ & $\begin{array}{c}\text { Periphery } \\
\text { (8) }\end{array}$ \\
\hline$\Delta \log ($ Sovereign CDS $)$ & $\begin{array}{l}0.127 \\
(4.39)\end{array}$ & $\begin{array}{l}0.111 \\
(2.06)\end{array}$ & $\begin{array}{c}0.0336 \\
(1.88)\end{array}$ & $\begin{array}{l}0.0475 \\
(1.94)\end{array}$ & $\begin{array}{l}0.0366 \\
(0.71)\end{array}$ & $\begin{array}{l}0.231 \\
(2.64)\end{array}$ & $\begin{array}{l}0.0110 \\
(0.62)\end{array}$ & $\begin{array}{l}0.138 \\
(4.27)\end{array}$ \\
\hline Time/Bank FE & $\mathrm{Y} / \mathrm{N}$ & $\mathrm{Y} / \mathrm{Y}$ & $\mathrm{Y} / \mathrm{N}$ & $\mathrm{Y} / \mathrm{Y}$ & $\mathrm{Y} / \mathrm{Y}$ & $\mathrm{Y} / \mathrm{Y}$ & $\mathrm{Y} / \mathrm{Y}$ & $\mathrm{Y} / \mathrm{Y}$ \\
\hline Foreign Exposure CDS & $\mathrm{Y}$ & Y & $\mathrm{Y}$ & $\mathrm{Y}$ & $\mathrm{Y}$ & $\mathrm{Y}$ & $\mathrm{Y}$ & $\mathrm{Y}$ \\
\hline Bank-level betas & $\mathrm{N}$ & Y & $\mathrm{N}$ & Y & Y & $\mathrm{Y}$ & Y & Y \\
\hline Balance sheet controls & Y & Y & Y & $\mathrm{Y}$ & Y & $\mathrm{Y}$ & Y & Y \\
\hline Observations & 9,824 & 1,413 & 15,200 & 5,612 & 520 & 893 & 1,489 & 4,123 \\
\hline Banks & 32 & 32 & 32 & 32 & 16 & 16 & 16 & 16 \\
\hline$R^{2}$ & 0.230 & 0.402 & 0.207 & 0.388 & 0.326 & 0.480 & 0.528 & 0.412 \\
\hline Adjusted $R^{2}$ & 0.205 & 0.281 & 0.181 & 0.323 & 0.187 & 0.316 & 0.382 & 0.329 \\
\hline
\end{tabular}


Table A.2: Change in Bank and Sovereign Credit Risk (pre-QE loan book shares: top vs. bottom)

Table A.2 shows the effect of sovereign credit risk on bank credit risk before and after the introduction of the Public Sector Purchase Programme (PSPP). The sample with daily frequency covers 21 banks with publicly traded credit default swaps (CDS) from 5 different euro area periphery countries. We sort the banks according to their loan book shares pre-QE. In particular, we compute the average share of loans over total assets from the first half of 2014. Top captures the banks with a share greater than the median. Bottom captures the banks with a share lower than the median. Columns (1) and (2) cover the pre-QE period (1 January 2014 to 8 March 2015). Columns (3) and (4) cover the post-QE period (9 March 2015 to 31 December 2016). $\Delta \log ($ Bank CDS) is the daily change in the natural logarithm of bank CDS. $\Delta \log$ (Sovereign CDS) is the daily change in the sovereign CDS of the country in which the bank is headquartered. We add a range of control variables, including bank and day fixed effects, the foreign exposure measure $\Delta \log$ (Foreign Exposure CDS), and interactions of bank fixed effects with the change in the CDS market index and the change in the volatility index. t-statistics are in parentheses and the stars ${ }^{* *},{ }^{* *}$, and $*$ indicate statistical significance at the $1 \%, 5 \%$, and $10 \%$ level, respectively.

\begin{tabular}{lccccc}
\hline & \multicolumn{3}{c}{$\Delta \log ($ Bank CDS) } \\
\cline { 2 - 3 } & \multicolumn{2}{c}{ Pre-QE } & & \multicolumn{2}{c}{ Post-QE } \\
\cline { 2 - 3 } \cline { 5 - 6 } & Top & Bottom & & Top & Bottom \\
& $(1)$ & $(2)$ & & $(3)$ & $(4)$ \\
\hline \multirow{2}{*}{$\Delta \log$ (Sovereign CDS) } & 0.177 & 0.185 & & 0.0432 & 0.0367 \\
& $(3.09)$ & $(4.28)$ & & $(5.55)$ & $(1.34)$ \\
& & & & & \\
Time/Bank FE & $\mathrm{Y} / \mathrm{Y}$ & $\mathrm{Y} / \mathrm{Y}$ & & $\mathrm{Y} / \mathrm{Y}$ & $\mathrm{Y} / \mathrm{Y}$ \\
Foreign Exposure CDS & $\mathrm{Y}$ & $\mathrm{Y}$ & & $\mathrm{Y}$ & $\mathrm{Y}$ \\
Bank-level betas & $\mathrm{Y}$ & $\mathrm{Y}$ & & $\mathrm{Y}$ & $\mathrm{Y}$ \\
Balance sheet controls & $\mathrm{N}$ & $\mathrm{N}$ & & $\mathrm{N}$ & $\mathrm{N}$ \\
Observations & 3,070 & 3,377 & & 4,630 & 5,093 \\
Banks & 11 & 10 & & 11 & 10 \\
$R^{2}$ & 0.321 & 0.280 & & 0.272 & 0.362 \\
Adjusted $R^{2}$ & 0.238 & 0.200 & & 0.186 & 0.294 \\
\hline
\end{tabular}

